ACTHOR'

BY THE BIBLIOGRAPHIC SERVICE, JANUARY 19

\title{
ASYMMETRICAL REGULATION IN ANURAN EMBRYOS WITH SPINA BIFIDA DEFECT
}

\author{
H. V. WILSON AND BLACKWELL MARKHAM \\ FIVE FIGURES
}

I

In fishes and amphibia it frequently happens that something interferes with the normal movement of the blastopore lip over the yolk. In these cases, familiar to embryologists, the anterior end of the axial body develops in front of the blastopore lip and is continuous behind with the two halves of the latter. Between these lateral halves in amphibia there lies bare yolk, whereas in fishes the exposed yolk mass may become completely or nearly covered in (Lereboullet's figures, '63) by a thin layer of tissue produced as an extension from the blastopore lips toward the median line. The embryos in the two groups are, however, essentially alike.

A survey of the facts leads to the following conclusions as to the ways in which such abnormalities may continue to develop:

1. Overgrowth may be merely slowed up, in which case nothing strikingly abnormal results.

2. The lateral halves of the blastopore lip organize into 'halfbodies.' Each half-body becomes a whole, and thus a double monster results. Hertwig ('92, p. 464) denies the possibility of this occurrence. But it was established as a fact by the observations recorded in Lereboullet's classic paper ('63; cf. especially Lereboullet's figs. 26 and 27, pl. III, and. figs. 28 and 29, pl. III). Roux maintained it ('88, p. 516) and Endres further established it ('96, p. 541). Lereboullet actually observed (loc. cit. passim; cf. pl. 2, fig. 6) in a number of cases the gradual fusion of the two bodies of a double embryo (formed perhaps in other ways than the above) into one body. This, then, would be one way open 
to such an embryo toward normality. Another way would be complete division.

3. The lateral halves of the blastopore lip organize into halfbodies, and these come together symmetrically in the midline to form a single embryo.

4. The lateral halves of the blastopore lip organize into halfbodies, but one atrophies while the other gives rise to an entire trunk. Or one lip fails to organize, while the other does so, first into a half-, then into a whole trunk. The two variants intergrade.

This paper describes two cases which fall in the fourth group.

II

\section{EMBRYO OF BUFO LENTIGINOSUS WITH ASYMMETRICAL REGULATION}

Eggs of Bufo had been artificially inseminated February 27th, and from a culture the great bulk of which were developing normally, the embryo in question was picked out March 4th. In this embryo (fig. 1), which has begun to lengthen, the neural plate is conspicuous, but the yolk plug is still large. The medullary folds are both continued backward on the left side of the blastopore, ending posteriorly in a little projection, $p . n$. , which is distinctly lifted above the neighboring surface. The axis of the neural plate is thus not straight, but posteriorly inclines somewhat to the left, while the blastopore has been pushed over toward the right. In the middle of the posterior (ventral) lip of the blastopore, and therefore at some distance from the posterior end of the neural plate, there are two very small knobs, t.b., representing the tail buds.

The embryo was sectioned, and figure 2 represents a section taken transversely through the posterior end of the neural plate and therefore across the yolk plug. The archenteron, arch, is large. The notochord has formed. The neural groove is present, with a medullary fold, $I m f$ and $r m f$, on each side of it, the left one the larger. The gastral or notochordal mesoderm, nc.m., is distinguishable on each side of the notochord, on the right pass- 
ing at once into the tissue of the blastopore lip, on the left thinning out at a little distance from the notochord into a sheet, which farther outwards is not distinguishable from the dorsolateral wall of the archenteron. Peristomal mesoderm, p.m., has begun to differentiate on the other side of the embryo extending ventrally from the right blastopore lip, r.b.l. Otherwise this lip, the right one, shows no differentiation.
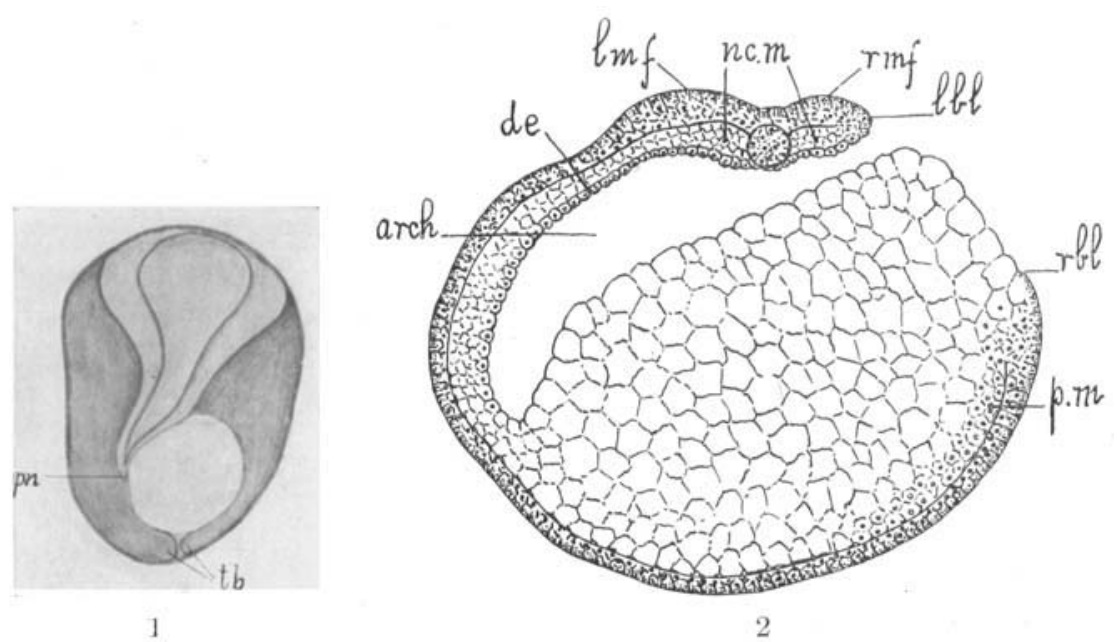

Fig. 1 Bufo embryo. Dorsal view. $p n$, posterior end of neural plate; $t b$, tail buds. $\times 18$.

Fig. 2 Transverse section of embryo shown in figure 1, through the blastopore. arch, archenteron; de, dorsal entoderm; $l b l$, left blastopore lip; $l m f$, left medullary fold; nc.m, gastral mesoderm; $p$ m, peristomal mesoderm; rbl, right blastopore lip; rmf, right medullary fold. $\times 40$.

It is clear that in this embryo a full set, not a half set, of axial structures had begun to develop on the left side of the blastopore. In this differentiation of the axial body, the right lip had no share.

\section{CHOROPHILUS LARVA WITH ASYMMETRICAL REGULATION}

'The frog larva next to be described (figs. 3, 4, and 5) represents fairly well a later stage of the embryo shown in figure 1, supposing that the asymmetrical regulation begun in the latter had gone on. This embryo appeared in a batch of normally develop- 
ing eggs of Chorophilus feriarum which had been artificially inseminated February 15th. It was early singled out by Mr. T. E. Rondthaler as one in which the blastopore did not close, and was kept under more or less continuous observation. It elongated and became somewhat flattened dorsoventrally, the yolk plug occupying a median dorsal position in the posterior part of the body. Immediately behind the yolk plug two tail buds, one left, one right, appeared. They both early acquired a spiral
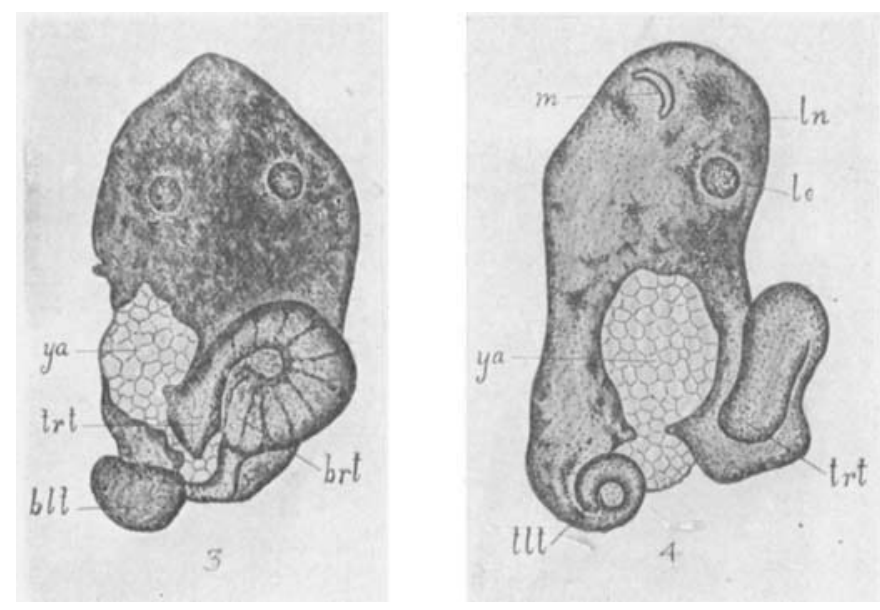

Fig. 3 Chorophilus larva. Dorsal view. blt, base of left tail; brt, base of right tail; trt, tip of right tail; $y a$, exposed yolk area. $\times 25$.

Fig. 4 Ventrolateral view, from the left, of larva shown in figure 3 . le, left eye; $l n$, left nostril; $m$, mouth; $t l l$, tip of left tail; $t r t$, tip of right tail; $y a$, exposed yolk area. $\times 25$.

curvature in different planes. External gills, which are small in this species, developed. With their disappearance and the steady increase in size of the head and trunk region, the yolk plug gradually shifted over toward the left side of the body. One tail, the left, was thus carried into a position which was distinctly ventral (fig. 4). The other tail, the right, which gradually became much the stouter, took up a position which was distinctly dorsal, its basal part directly in line with the median longitudinal axis of the trunk (fig. 3). 
By this time the larva showed well-developed eyes, mouth, and nostrils, and was about $2 \mathrm{~mm}$. long with a greatest breadth of $1 \mathrm{~mm}$. It did not die naturally, but was preserved, March 8th. At that time it seemed to be in good health with a fair prospect of living on. Sections showed that internal gills and the opercular cavity were well developed. The right tail had relatively large dorsal and ventral fins in its posterior part, and at its tip the left tail likewise had fins. The exposed yolk area

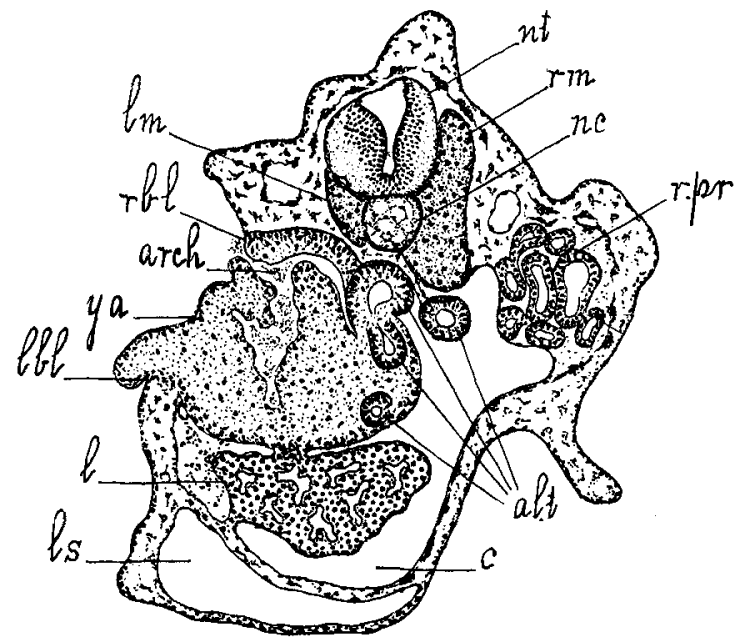

Fig. 5 Transverse section of larva shown in figures 3 and 4 , through anterior end of yolk mass. arch, archenteron; alt., tubes representing an alimentary canal in process of formation; $c$, coelom; $l$, liver; $l b l$, left blastopore lip; $l m$, left myotome: $l s$, lymph sinus; $n c$, notochord; $n t$, neural tube; rbl, right blastopore lip; rm, right myotome; rpr., right pronophros; $y a$, exposed yolk area. $\times 67$.

measured in length about one-half the total length of the body. Internally the yolk mass was found to occupy slightly more than this ratio.

A study of the internal anatomy as made out in a series of transverse sections gave the following facts: The brain, eyes, auditory sacs, nostrils, mouth, pharynx, gills (internal), opercular cavity, and heart showed nothing obviously abnormal. But in the trunk and tail region there were numerous results that had followed from the failure of the blastopore to close. We 
take these up in order, as affecting the alimentary canal, spinal cord, notochord, myotomes, and pronephros.

Alimentary canal. The anterior end and the pharyngeal region of the alimentary canal have the usual anatomy, appearing as parts of a wide, straight passage. This comes to an end at the anterior limit of the yolk mass. The latter in this region is found to be excavated by numerous tubular channels, round which the cells are arranged in epithelial fashion. A few other similar tubes with less yolk in the cells lie at the surface of the mass (fig. 5). It is possible to trace some interconnections between these, and the tubes are perhaps all interconnected, representing an alimentary canal in the making. A remnant of the original archenteron persisting as a shallow slit-like cavity, which extends well into the yolk and connects with the exterior round the right lip of the blastopore, is present in this region (fig. 5, arch). It connects with, at any rate some of, the tubular channels above referred to. Possibly it forms the terminal, anal, part of the alimentary canal which is in process of differentiation. The posterior and much the greater part of the yolk mass remains as solid and compact and undifferentiated as in a gastrula stage.

It is clear that in this larva an alimentary canal was in process of formation by a method different from the normal. The departure is probably adaptive to the continued presence of the yolk mass. In the figurative language of vitalism, the embryo makes an effort to form an alimentary canal, although the customary road to that end is not open. Moving slightly away from vitalism, we seem to see the destined end of the ontogeny working backward as a cause, a philosophic idea which certain embryological writers (cf. Jenkinson's admirable book, '09, p. 20) have in recent years shown a willingness to adopt into our family of concepts concerning the processes at work in ontogeny. To invoke such retroactive influences may, as Jenkinson says, in the end prove necessary, but on the other hand it may not. The fact is that while the idea of individual adaptation or regulation in ontogenetic processes is now familiar to us, the detailed facts (comparative and experimental) of any particular set of cases 
have only been touched upon in a preliminary, reconnoitering sort of way. Brilliant as the results are, they need to be interwoven with rich collections of special knowledge, which shall combine the data of experimental organogeny with tabulations of the various organogenetic methods practiced by sets of individuals, and races, of a species and by related species. Twentyfive years ago, one of the writers mapped out in a descriptive paper (Wilson, '94) this plan as affecting the study of the comparative embryology of sponges. The idea was to learn something, through comparison, of the kinds of changes that may be made in the ontogenetic processes of a race and the laws governing their appearance. The comparative study remains as important to-day as it was then, and the field is almost as virgin. In a word, before accepting this conclusion that the end sets in activity the means, we need to know in any particular case much more both about it and allied cases. Ontogeny we picture as an intricate series of events, each event setting free stimuli which bring about other events. If, then, a certain event does not occur, the embryo in respect to this point may, for all we know, fall back to a lower level, to a more generalized ancestral condition, in which it makes responses such as it would have made in former times. Or it is possible that steps in ontogeny not directly dependent on the occurrence of the inhibited event may continue to be made, one after another, and thus we may come out with an embryo in which only a part is missing, in which case the missing part might conceivably be supplied as if it had developed, had been lost, and now were being regenerated. All this, of course, is conjecture, but it is at least physiological.

Liver. The liver appears as a large cellular mass excavated by abundant sinuses which divide it up into cords. It is intimately connected, throughout most of its extent, with the yolk mass, shading off into the latter in places.

Spinal cord. The spinal cord in the trunk region, as far back as the base of the right tail, is symmetrical, one side having the same amount and arrangement of incipient gray and white matter as the other. At the base of the right tail, the spinal cord is continued into a tube with a much wider lumen. The wall of 
this caudal continuation of the cord is markedly thicker on its morphological right side than on the opposite side. On the former side it consists of a high lining epithelium, outside which lie some rounded cells and then a little white matter, whereas on its left side the wall consists only of a layer of low epithelium. The tube narrows to one which still presents a relatively large lumen, but the wall of which is nearly uniform in thickness, consisting of a simple columnar epithelium. It extends nearly to the tip of the tail.

Summing up for the neural tube, it may be said that the neural tube of head and trunk is continued directly into the right tail. Elsewhere symmetrical, in the right tail it gives an indication of being a half-cord. In the left tail and along the left lip of the blastopore there is no sign of a neural tube.

Notochord. The cylindrical notochord of the posterior head region and trunk is continued directly into the right tail with no diminution in size. It extends the whole length of the tail, remaining cylindrical, but decreasing gradually in diameter in the usual way. In the left tail and along the left blastophore lip there is no sign of a notochord.

Myotomes. The myotomes of the trunk are as in figure 5 . There are two series, but those on the right side, $r m$, are strongly developed, those on the left side, $l m$, very small. The series of strongly developed myotomes on the right side of the body is continued into the right side of the right tail, and the series of small myotomes on the left side of the body into a similar series on the left side of this tail. This disproportion in size, between the two series of myotomes in the tail, is as great or greater than in figure 5. The series of right-hand myotomes is continued almost to the tip of the tail. The series on the opposite side comes to an end shortly behind the basal part of the tail. In respect to the myotomes, then, the basal part of this tail is similar to the trunk (fig. 5), but the greater part is more distinctly a half-tail in that it lacks myotomes on one side. Doubtless these were developing from before backward, when the larva was killed. 
The other, originally left, tail has a distinctly developed series of small myotomes on one side, the side turned away from the yolk mass (originally the left side). This extends from about the tip of the tail to its base and forward as a very small stripe for some distance, close to the morphological left lip of the blastopore, fading away anteriorly. It is evident, then, that the left lip of the blastopore had made steps toward organization. But the regulatory processes going on along the other lip made these steps futile.

Pronephros. The right pronephros, figure 5, r.pr., is well developed and the right Wolffian duct extends backward through the trunk. What appears to be the left Wolffian duct is present near the left blastopore edge, about the middle region of the body, extending through a number of sections. The anterior end of this tube could not be traced. Thus whatever steps have been taken to form a left pronephros have not gone beyond the merest start.

In the embryo just described the axial organs (neural tube, notochord, myotomes) have not, it is clear, been built up by the fusion in the middorsal line of two halves. Instead, an asymmetrical method has been followed, the fundamental feature in which is the utilization of only one blastopore lip. The steps in this process are briefly as follows: 1) The exposed yolk area is shifted over toward the left side. 2) The right blastopore lip and the right tail bud are thus brought in line with the median axis of the head end. 3) The right lip organizes a backward continuation of neural tube, notochord, and the right series of myotomes, all continued into the right tail bud, which grows much larger than the left one. 4) After having established axial organs in the trunk region, the right blastopore lip grows for some little distance over the exposed yolk, thus coming to lie to the left of the median body plane. A series of myotomes is then organized along the left side of the notochord. 5) The left lip of the blastopore and the left tail bud make no more than the first steps toward organization.

The behavior and the anatomy of the larva at the time of preservation indicated that the process of establishing the normal 
structure would have gone farther had the larva been allowed to live. The yolk mass was apparently being covered in through further extension over it of the blastopore lips. The mass itself had made some headway toward transformation into a part of an alimentary canal. The left series of myotomes would probably have extended itself to the tip of the tail (right tail), and would have continued to grow in size. With the continued dorsal extension of the coelom on the left side of the body (fig. 5 ), the conditions for the formation of a left pronephros, to match that already developed on the right side, would have been more nearly realized. Absorption of the left, small tail would have completed the steps by which, in spite of its failure to go through certain early phases of the normal cycle of changes, the embryo might in the end have acquired the type structure. We hope at some later date to have actual observations to report on the final stages in the restoration of such asymmetrically developing larvae, if indeed they do succeed in going through the entire process. It is to be expected that here, as elsewhere, in respect to the actual details, individuals will vary.

Cases essentially similar to the above have been recorded by Lereboullet ('63) for the teleosts. In the embryo shown in his figures 30 and 31, pl. III, one of the half-bodies degenerates, while the other develops into a whole body. This latter comes to lie in direct line with the head end. We thus get what is not far from a normal embryo, a lobe-like projection from one side and a split tail alone remaining to indicate the original duplicity. This conclusion, which Lereboullet draws, is made practically certain by the several embryos which he describes and which individually illustrate different stages in the process. Indeed, in the case of another embryo like his figure 31, Lereboullet was able to observe from day to day the gradual degeneration of one of the half-bodies. In another closely similar case, only briefly described, no. 55, loc. cit., p. 224 , it would seem that only one blastopore lip became organized as a half-body, but Lereboullet is not very explicit here.

The frog embryos studied by O. Hertwig ('92) do not, as he points out, all conform to the symmetrical type of development. 
For in some of them the organs develop in very unequal degree in the two lateral blastopore lips. This asymmetry is extreme in the embryo pictured by Hertwig in figures 15 and 16 of $\mathrm{pl}$. XVI and figure $27 \mathrm{po} \mathrm{pl}$. XVIII. In this individual development had gone so far that eyes and suckers had been formed. Nevertheless, nearly the whole of the dorsal surface was occupied by an exposed yolk area. The special point of interest is that one of the lateral blastopore lips was found to be not organized at all. The opposite lip, on the contrary, contained a small neural tube and notochord, which anteriorly were continued into the corresponding structures of the very short head end and posteriorly into a well-developed tail (half-tail or tail bud). Hertwig regards this interesting embryo merely as one in which the axial half-structures developed on one side and not on the other. $\mathrm{He}$ does not view or discuss it as illustrating a step in the direction of forming a whole trunk out of one blastospore lip. And indeed it may not illustrate such a step, although it obviously presents a close analogy to the Chorophilus embryo described above.

Endres and Walter ('95) described a frog embryo in which possibly a process was going on similar to that in our asymmetrical embryos. They, loc. cit., p. 41 and passim, find with Roux that half-embryos, developing from one of the first two blastomeres, restore more or less completely through 'postgeneration' the missing organs of the other side. In the case referred to (Hemi-embryo sinister: F, loc. cit., pp. 43 to 48 ) there is a large, dorsal, exposed yolk area. One blastopore lip is well organized and passes backward from the head end into a well-developed tail. The other, the 'post-generated' lip, is very imperfectly organized.

\section{III}

The common or typical regulatory method of establishing the type structure employed by embryos in which the closure of the blastopore has been extensively interfered with, is generally thought to be that in which both lips organize and come together symmetrically in the midline (group 3, p. 172). And there seems to be no doubt that this method is employed sometimes, although observations on its occurrence in an actual embryo are scanty. 
Lereboullet records some direct evidence for the teleosts. In case no. 56 (loc. cit., p. 225 , figs. 32,33 , and 34 ) he watched the actual development of the embryo from day to day. Anteriorly and posteriorly some fusion of the two half-bodies apparently took place, although as late as the seventh day the half-bodies were still separate throughout an extensive part of the trunk, and no further fusion took place during the remaining five days of the embryo's life. It is, however, probable that the now common view, which Lereboullet advanced, applies to this case and that under favorable circumstances the two half-bodies would have completely fused. The truth of this idea is made almost certain by cases like Lereboullet's no. 57 (loc. cit., p. 226), in which the half-bodies have been brought so close together as to be practically in contact, and his no. 59 (loc. cit., fig. 35), in which at the posterior end of the single trunk there is found a small dorsally situated aperture, interpreted as the remnant of the blastopore.

O. Hertwig, in his well-known paper ('92) on frog embryos exhibiting the spina-bifida defect, describes many such embryos in anatomical detail. He arranges them in a series which he interprets as representing the actual ontogeny. His series begins with the so-called 'ring embryos,' in which the exposed yolk area is very large and the part of the axial body lying in front of the blastopore lip very small - so small, indeed, that it includes no more or scarcely more than the anterior cerebral commissure. In such embryos he concludes with Roux ('88) that the lateral lips of the blastopore become organized into half-bodies, which gradually meet in the midline. And the individual frog embryos which he describes and arranges in a series represent, he thinks, successive stages in the actual ontogeny of such a 'ring embryo.' It is far from certain that all of the abnormalities, so arranged, really belong in a single ontogenetic series. Nevertheless, the data, recorded with admirable precision, doubtless justify the conclusion that sometimes the lateral lips do organize and come together in frogs, as Lereboullet had already claimed was the case in fishes. But Hertwig has no observations on the actual occurrence of this process in one and the same embryo. 
In fact, direct observations on the occurrence of the symmetrical fusion of half-bodies are, as we have said, few and scanty. They lack detail. Nevertheless, Roux ('88, p. 443) has actually watched the gradual approximation of the lateral lips of the blastopore in frog embryos exhibiting the spina-bifida defect (designated by him, consistently with his theory, asyntaxia medullaris), until the blastopore had quite closed.

This symmetrical mode of development of spina-bifida embryos is looked on by many embryologists (cf. especially Roux, '88, pp. 443-444, and O. Hertwig, loc. cit.) as not fundamentally different from the normal embryology. The difference, according to these writers, is that, whereas in normal development the lateral blastopore lips come together before they are organized, in the spina-bifida embryos their fusion is so delayed that they become organized first. Thus the organization of the blastopore lips in a spina-bifida embryo is not looked on as an abnormal regulation that starts up when something checks the activity of the morphogenetic process by which the body is usually lengthened. It is, on the contrary, a process that is perfectly normal in itself, only out of place in time. This is the point of view of the concrescence theory of vertebrate ontogeny.

Undoubtedly, symmetrical spina-bifida embryos strongly suggest the idea of concrescence -so strongly, indeed, that they are thought of by some as almost demonstrating the truth of its occurrence in normal development. But this reasoning is obviously vicious, since it begs the question as to whether organization of the lateral lip is a normal process (although out of place in time) or a radically abnormal one. Such radically abnormal regulatory processes of course occur. Driesch and many others have made us far more familiar with them than were the older embryologists. And in establishing or restoring the type structure, their disregard of the customary mode of attaining that end is well known. Following this line of thought, we may entertain the idea that the organization of the blastopore lip in the embryos in question is a thoroughly abnormal process, as far away, although in a different direction, from the normal mode of forming the axial body as is the process, for instance, in those rare teleost 
monsters, in which the blastoderm does not grow round the yolk, but remains small, while an embryonic body is developed extending completely through it from posterior to anterior edge (Kopsch, '04, p. 95, Taf. X, Fig. 118).

If the organization of the lateral blastopore lip is an unusual, abnormal process, spina-bifida embryos become no less interesting than they have been hitherto, since they tell us plainly that here is tissue which may be activated to develop, in very atypical fashion, into certain of the specific structures. From this point of view, such embryos may be thought of as arising in the following fashion. The axial body which normally forms in front of the blastopore lip is short. It grows in length especially at the posterior end which is carried backward, the growth being in part due to the incorporation of tissue belonging to the blastopore lip. The indifferent mass of tissue at the posterior end of this embryonic body is constantly being organized and added to the organs in front of it, some to neural tube, some to notochord, etc. Frankly abandoning deterministic theories which would see in the tail bud of a vertebrate embryo not indifferent tissue, but neural, notochordal, and other kinds of cells, we ask what brings it about that certain cells go to one, other cells to another organ? Plainly O. Hertwig and the thinkers of that school are right; it is position that determines the fate of the cells. Those behind the notochord become notochord. Those behind the neural tube become neural tube. What underlies this phenomenon? The answer seems clear: the already differentiated organ, notochord, e.g., exerts a controlling influence on the contiguous, indifferent cells behind it and makes them into its like. ${ }^{1}$

Now when the backward growth of the blastopore lip (to be construed as part of the general closure of the blastopore), and hence of the axial embryonic body, is prevented, what is the sit-

\footnotetext{
${ }^{1}$ Roux has discussed this kind of influence ("eine eigenthümliche ordnende und gestaltende Wirkung," 1888, p. 505 and passim) in the case of half-embryos of the frog produced by killing, or nearly killing, one of the first two blastomeres. In the formation, 'postgeneration,' of germ layers in the operated half, the organizing influence extends outward from the edge of each, already formed, germ layer of the normal half. This progressive differentiation of relatively indifferent stationary material, where the "differentiative stimulus passes from the al-
} 
uation? The embryo finds itself unable to elongate directly, and yet continuous at its posterior end with two stripes of indifferent tissue. These are accordingly, under the general influence of the regulatory tendency; organized through the action of the structures in front, precisely as the growing tail bud is organized in the normal embryo. The difference is that in the spina-bifida embryo the entire stripe is there from the start, while the cord of cells, to which the backwardly growing tail bud gives rise, is formed and metamorphosed into its several derivatives gradually.

There are still other ways in which we may conceive of spinabifida embryos as being formed. Kopsch ('96, '99, '04) and $\mathrm{H}$. V. Wilson ('00), for instance, have held that it is not necessary to regard them as due to organization in situ of the blastopore lips, but that they may be produced as the result of a progressive splitting of the axial body. This explanation may well apply to some cases.

It is plain that spina-bifida embryos of themselves will not tell us whether they have been built up by normal or abnormal processes. If the blastopore lip organizes, we may claim with one school that it is a normal process, with the other that the lip has been activated perhaps in the manner described above. If it does not organize, as may happen, we may adduce this as proof that there is no normal impulse in it toward organization, or with the other school that the normal impulse has been inhibited. In the midst of this debating one does not forget, however, that the proximate, so-called practical, thing to do is to learn how to control the differentiation of the lip, to call out in it, or prevent perhaps, the formation of a neural tube, notochord, and somites.

ready differentiated cells" into the indifferent mass, falls in Roux's category of 'dependent differentiation' ('abhängige Differenzirung'). The directive force Roux designates 'an assimilative and differentiative action,' (loc. cit., p. 509). To it is applicable the term 'morphological assimilation' (Roux, '12, p. 28), which might be used, pending the coinage of an appropriate Greek word. Other embryologists had already postulated the existence of such an influence in normal development, but Roux, I believe, for the first time gave precision to the idea. 
Whether in ordinary development there is a virtual concrescence of lateral blastopore lips in the midline, and eventual organization of these, is a question which is most definitely answered not by a study of monsters, but by analytical studies on the normal embryo. Some years ago one of the present writers (Wilson, '00, '01) published data which together with the work of $O$. Schultze (ref. in Wilson, loc. cit.), Assheton (ref. in Wilson, loc. cit.), Kopsch ('00 and earlier papers), Eycleshymer ('02 and earlier papers), Ikeda ('02), seem to make the concrescence theory untenable for the amphibian egg, since they necessitate the conclusion that a considerable part of the dorsal axial body is formed in situ, viz., in front of the dorsal blastopore lip where it first forms. That the posterior part of the dorsolateral wall of the embryo (gastrula) is produced by the backward growth of the corresponding part of the blastopore lip is admitted by everyone, but it is plainly arbitrary to construe this as a modified form of concrescence. All parts of the blastopore lip grow backward, dorsal, lateral, and ventral. The difference in the distance covered by dorsal and ventral lips in the frog is, to be sure, considerable, but this inequality is readily understood as a part of the general asymmetry in gastrulation-an asymmetry due to the acquisition and distribution of yolk in the egg, as Balfour long ago pointed out.

Likewise the data adduced for fishes by Morgan ('95), Kopsch (Kopsch's splendid study published 1904 contains references to his earlier papers), and Sumner ('00, '03) make it practically impossible to believe that concrescence normally occurs in these forms.

That the concrescence theory may contain truth as a phylogenetic theory, in other words, that concrescence may have actually occurred in the evolution of the distinctly bilateral metazoa from coelenterate-like forms, remains of course possible. And with richer and more precise knowledge, such questions doubtless will be taken up again in the future.

Lereboullet is often cited as an adherent-in fact, as the first promulgator-of the concrescence theory. But this is to read into his paper ('63) an interpretation that is not, I believe, war- 
ranted. He recognizes that the fish body is first marked out as a projection reaching forward from the blastodermic rim. This 'tubercle,' in normal development as in double-embryo formation where two tubercles are formed, elongates to form a linear body ('bandelette embryonnaire'). Lereboullet speaks of the production of the original tubercle as due to a sort of 'vegetation' from the blastodermic rim (a description that is clearly not warranted). As to the processes involved in its elongation, he is not explicit. But it would seem that he means that the tubercle elongates by its own growth, possibly incorporating the neighboring tissue of the blastodermic rim (which no one would deny). By contrast, in his fourth kind of anomaly, what we call to-day the spina-bifida embryo, the original tubercle does not grow and elongate, but the lateral blastodermic edges organize and participate directly, as such, in forming the body. In fact, in his search for the growth processes that lead to his various anomalies, he gives the impression of having distinctly in mind the power of the embryo to proceed to the type structure in more ways than one. Whereas, some of the later embryologists, like o. Hertwig, assume for the moment at least that ontogeny always exhibits the same series of events, anomalies being due to retardation or acceleration in the occurrence of particular events. While undoubtedly many anomalies are produced in this way, there are as certainly others the causation of which is much more subtle and complex.

\section{SUMMARY}

Bufo and Chorophilus embryos occur in which, when blastopore closure is inhibited, an asymmetrical regulatory process comes into activity. Instead of the two lateral blastopore lips fusing in the midline, the blastopore is shifted over toward one side, and from a single lip a backward extension of the axial organs is produced. Such a tadpole was reared to a stage in. which external gills had been absorbed, internal gills and opercular cavity formed.

University of North Carolina

Chapel Hill, North Carolina 


\section{LITERATURE CITED}

Endres, H., ANd Walter, H. E. 1895 Anstichversuche an Eiern von Rana fusca. Erster Theil. Archiv f. Entw.-mech., Bd. 2, Heft 1.

Endres, H. 1896 Anstichversuche an Eiern von Rana fusca. Zweiter Theil. Ibid., Bd. 2, Heft 4.

Eycleshymer, A. C. 1902 The formation of the embryo of Necturus, with remarks on the theory of concrescence. Anat. Anzeiger, Bd. 21.

Hertwig, O. 1892 Urmund und Spina bifida. Arehiv f. mikr. Anat., Bd. 39.

IKeDA, SakujIro. 1902 Contributions to the embryology of amphibia: The mode of blastopore closure and the position of the embryonic body. Journ. Coll. Science, Imp. Univ. Tokyo, vol. 17, part 2.

Jenkinson, J. W. 1909 Experimental embryology. Oxford.

Kopsch, Fr. 1896 Exper. Unters. ü. d. Keimhautrand d. Salmoniden. Verhdlg. d. Anat. Gesellsch. zu Berlin.

1899 Die Organisation d. Hemididymi, etc. Intern. Monatsschr. f. Anat. u. Physiologie, Bd. 16.

1900 Über das Verhältniss d. embryonalen Axen zu d. drei ersten Furchungsebenen beim Frosch. Ibid., Bd. 17.

1904 Unters. ü. Gastrulation u. Embryobildung bei den Chordaten. I. Die morphologische Bedeutung d. Keimhautrandes u. die Embryobildung bei der Forelle. Thieme, Leipzig.

LeReBodluet, A. 1863 Recherches sur les monstruosités du Brochet observées dans l'oeuf et sur leur mode de production. Ann, des Sei. Naturelles, 4me série, Zoologie, T. 20.

Morgan, T. H. 1895 The formation of the fish embryo. Jour. Morph., vol. 10.

RoUx, Wilfelm 1888 ťber die künstliche Hervorbringung 'halber' embryonen durch Zerstörung einer d. beiden ersten Furchungszellen, etc. Virchow's Archiv, Bd. 114 (Roux, Gesammelte Abhandlungen ü. Entw.mech., Bd. 2, to which page references are made).

1912 Terminologie der Entw.-mechanik. Leipzig.

Sumner, F. B. 1900 Kupffer's vesicle and its relation to gastrulation and concrescence. Mem. New York Acad. Sci., vol. 2, part 2.

1903 A study of early fish development. Experimental and morphological. Archiv f. Entw.-mech., Bd. 17.

WiLson, H. V. 1894 Observations on the gemmule and egg development of marine sponges. Jour. Morph., vol. 9.

1900 Formation of the blastopore in the frog egg. Anat. Anzeiger, Bd. 18.

1901 Closure of the blastopore in the normally placed frog egg. Ibid., Bd. 20. 